\title{
実験的蓚酸カルシウム結石の研究
}

2. フィチン及びクェン酸の抑制効果について

$\begin{array}{cllll} & \text { 戎 } & \text { 野 } & \text { 庄 } & \text { 一 } \\ & \text { 森 } & \text { 本 } & \text { 鎮 } & \text { 義 } \\ & \text { 深 } & \text { 谷 } & \text { 俊 } & \text { 郎 } \\ \text { 和歌山県立医科大学泌尿器科学教室 } & \text { 宮 } & \text { 崎 } & \text { 善 } & \text { 久 } \\ & \text { 安任 } & \text { 川順正教授) } & & \text { 修 } \\ & \text { 澤 } & \text { 田 } & \text { 佳 } & \text { 久 } \\ & \text { 大 } & \text { 川 } & \text { 順 } & \text { 正 }\end{array}$

\section{STUDIES OF EXPERIMENTAL CALCIUM OXALATE STONE}

2. The Preventive Effects of Phytin and Citrate on Renal Deposition of Calcium Oxalate Induced by Ethylene Glycol Administration

Shoichi Ebisuno, Shigeyoshi Morimoto, Toshiro Fukatani, Yoshihisa Miyazaki,

Shu Yasukawa, Yoshihisa Sawada and Tadashi Ohkawa

Department of Urology, Wakayama Medical College

(Director: Prof. T. Ohkawa)

Previous study has shown that high-Ca diet develops severe renal tubular calcium oxalate deposition in rats on a hyperoxaluric protocol of ethylene glycol administration. The present study was conducted to investigate the preventive effects of phytin (extracted from rice-bran) and sodium citrate on intratubular calcium oxalate. These objectives were estimated using a histological grading (Grade 0-Grade 3 ) and calcium contents of whole renal tissue.

When rats fed by high-Ca diet were supplemented with phytin $(3 \mathrm{~g} / 100 \mathrm{~g}$ diet), a partial but significant protection aginst calcium oxalate deposition was achieved histologically and biochemistrically. It appeared that the hypocalciuric action of phytin was attributed to the inhibition of crystal formation.

Investigations of the effect of citrate on calcium oxalate crystal in rats were carried out continuous by administration of sodium citrate $(0.5 \%-2.5 \%)$, giving drinking water ad libitum. There were significant inhibitions of renal deposition of calcium oxalate by addition of citrate, even at the lowest concentration $(0.5 \%)$. The effectiveness of the protection of calcium oxalate crystal was ocrrelated directly with the level of citrate concentration.

要旨：第 1 報で報告したエチレングリコール投与によるラット実験結石モデルを用いて，米棣から抽出 されたフィチン及びクェン酸ナトリウムを投与し，腎尿細管内蓚酸カルシゥム結晶形成に対する抑制効 果を組織学的及び生化学的に検討し以下の結果が得られた。

（1）フィチン投与（3\%/高カルシウム食 $100 \mathrm{~g}$ ）により，尿中カルシウム排泄量は著明に減少し，且つ 腎尿細管内結晶形成も明らかに抑制された。これはフィチン投与に伴う尿中カルシウム排泄量の低下に よるものと考朰れた。

(2) クエン酸ナトリウムの投与に打いては, $0.5 \%$ 投与群でも明らかに腎尿細管内の結晶形成の抑制が 確認され，1.0\%及び $2.5 \%$ と投与量の増加に従いその抑制効果が増加した. 
著者らはこれまでに過カルシウム尿症を伴らカルシ ウム結石症の治療として米糠療法を提唱し，その基礎 的並びに臨床的検討の結果を既に報告しており，尿中 カルシウム排泄量の著明な減少と結石発生率の低下を 認めると共に，その主たる作用機序は米棣中に含まれ るフィチンによる腸管内でのカルシウム吸収抑制であ ることを明らかにし, 本法がカルシウム結石症の再発 防止として優れた一治療法であることを主張して来て

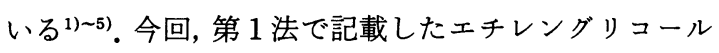
(以下 EG と略す)を用いる実験的蓚酸カルシウム結石 モデルを用いて，高カルシウム食飼育ラットに米糠か ら抽出したフィチンを投与し, 腎尿細管内の蓚酸カル シウム結晶形成に抑制がみられ得るか否かを検討した のでこの結果を記載し, 若干の考察を加える.

又, 低クエン酸尿がカルシウム結石患者におけるあ る種の risk factorになると云う指摘は以前より散見 されているところであるが, 最近になって結石の治療 にクェン酸が投与される試みが報告されて来ている. そこで, 今回フィチンと同様にクェン酸の投与も試み ラットの腎尿細管内での葆酸カルシゥム結晶形成に対 する効果をも検討したのでこの結果も併せ記載する.

\section{方 法}

実験動物及び飼料：実験動物は体重130～190g の雄 Sprague-Dawley ラット(日本クレア)を用い, 飼育飼 料は Table 1に示した如くの高カルシウム食及び高カ ルシウム・フィチン食を使用した。
Table 1 Constituents of experimental diets

\begin{tabular}{lcc}
\hline \multicolumn{1}{c}{ Diet } & High-Ca diet & High-Ca+3\% phytin diet \\
\hline Calcium (mg\%) & 1725 & 1760 \\
Magnesium (mg\%) & 338 & 249 \\
Total phosphorus (mg\%) & 660 & 993 \\
Phytate phosphorus (mg\%) & 11 & 340 \\
\hline
\end{tabular}

飼育及び実験方法：今回のフィチン及びクエン酸投 与の飼育及び実験方法はFig. 1に示した。フィチン投 与実験群は 1 週間高カルシウム食と蒸留水の自由摂取 で飼育され，引き続き高カルシウム・フィチン食に変 更の上, 蒸留水で 1 週間飼育された後に $1 \% \mathrm{EG}$ を飲 料水として 3 日間のみ自由摂取といら条件で飼育（以 下 $1 \% \mathrm{EG}$ 導入群とする)し，この時点で半数を屠殺し 以下に記載する検討を招こなった。他方, 残る半数は $0.1 \% \mathrm{EG}$ を飲料水として自由摄取させ，更に 2 週間の 飼育が維持（以下 $0.1 \% \mathrm{EG}$ 維持群とする）された。 ク エン酸投与実験群は 1 週間高カルシウム食と蒸留水の 自由摄取で飼育され，引き続き高カルシウム食の摂取 を続行しながらクエン酸ナトリウムを各々 $0.5 \%, 1 \%$ 及び $2.5 \%$ となるように添加した蒸留水で 1 週間飼育 された後に，更にその飲料水中に $\mathrm{EG}$ を $1 \%$ となるよ うに加えたものを自由摂取させる条件下で 3 日間飼育 し,この時点で半数を屠殺した. 残る半数はクェン酸 ナトリウムの添加濃度を変えずに EG 濃度を $0.1 \%$ に

Fig. 1 Protocols of two experiments.

(1) Experiment 1 (phytin study)

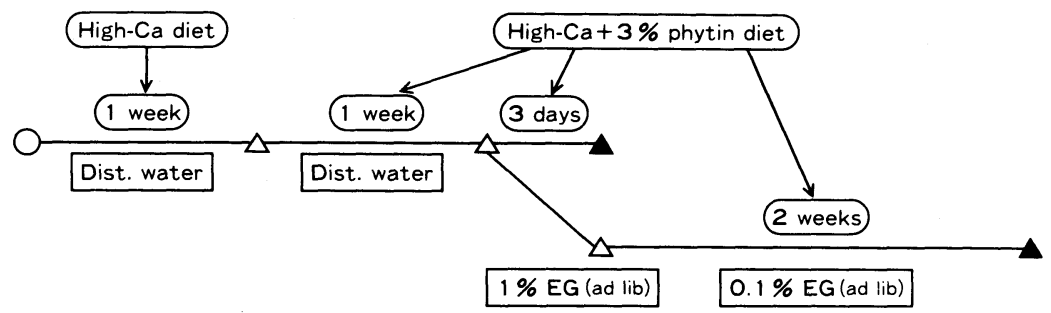

(2) Experiment 2 (citrate study)

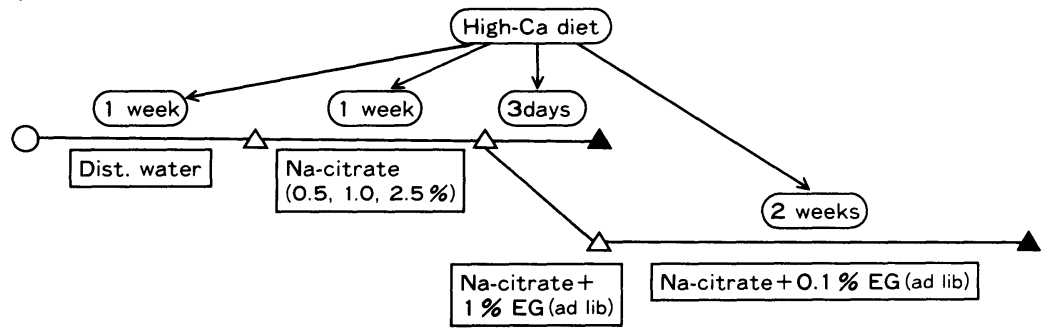


した飲料水で更に 2 週間飼育を維持した後，屠殺し検 討した. 各グループのラット数は $0.5 \%$ クェン酸ナトリ

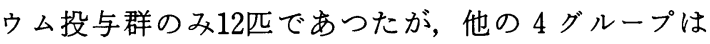
各々20匹で検討した。

各グループは高カルシウム食での飼育開始後 1 週間 目, 高カルシウム・フィチン食あるいはクエン酸ナト リウムのみ投与後 1 週間目, $1 \% \mathrm{EG}$ 投与 3 日目及び $0.1 \% \mathrm{EG}$ 投与 2 週目には代謝ケージ内に収容し，24時 間尿の採集及び採血を招こない，血清中ではクレアチ ニン，カルシウム及びマグネシゥムを測定し，尿中で はクレアチニン, カルシゥム, マグネシウム及び蓚酸 の排泄量をそれぞれ測定した。

血中及び尿中の関連物質の測定法並びに腎尿細管内 の鉴酸カルシウム結晶の沈着の検討方法た第 1 報と同 様に扣こなった。

又, フィチン投与実験群及びクェン酸投与実験群の 対照群としては第 1 報の高カルシウム食群が用いら れ, 統計学的処理は $\mathrm{t}$-検定において $99 \%$ 以上の信頼性 のあるものを有意の差があるものとした.

\section{結果}

（1）血清クレアチニン，カルシウム及びマグネシウ 厶

高カルシウム食群をも含めた 5 群の血清クレアチニ ン, カルシウム及びマグネシウムの測定值は Table 2
に示した。

血清クレアチニンは高カルシウム食群の $1 \% \mathrm{EG}$ 投 与 3 日目が著明な高値を示しており, 高カルシウム・ フィチン食群では $1 \% \mathrm{EG}$ 投与期にわずかに上昇傾向 を示している. 又, クェン酸ナトリウム投与の $0.5 \%$ 群 では $1 \% \mathrm{EG}$ 投与により有意の上昇を示したが, $1.0 \%$

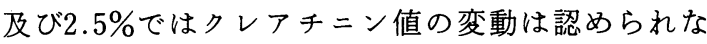
かった。

血清カルシウム値の上昇は対照群である高カルシウ ム食群のみで観察された。、グネシウムは高カルシウ ム食群及び高カルシウム・フィチン食群の $1 \% \mathrm{EG}$ 投 与 3 日目に扔いて高値がみられ，逆にクェン酸ナトリ ウム投与の $1.0 \%$ 及び $2.5 \%$ 群では EG の投与期間にマ グネシウムの低值が認められた。

（2）尿中カルシウム，マグネシウム及び蓚酸排泄量 高カルシウム食群をも含めた 5 群のクレアチニン比 で求めたカルシウム，マグネシウム及び蓚酸の排泄量 は Table 3に示した.

尿中カルシウムは高カルシウム・フィチン食群では フィチンの投与により約 $1 / 2$ 量に減少して扣り,クェン 酸の投与量が大量になると尿中カルシウムの減少する 傾向がみられた。

尿中マグネシウム排泄は $1.0 \%$ 及び $2.5 \%$ のクン酸 投与群の $0.1 \% \mathrm{EG}$ 維持群で低値が観察された.

Table 2 Serum creatinine, calcium and magnesium

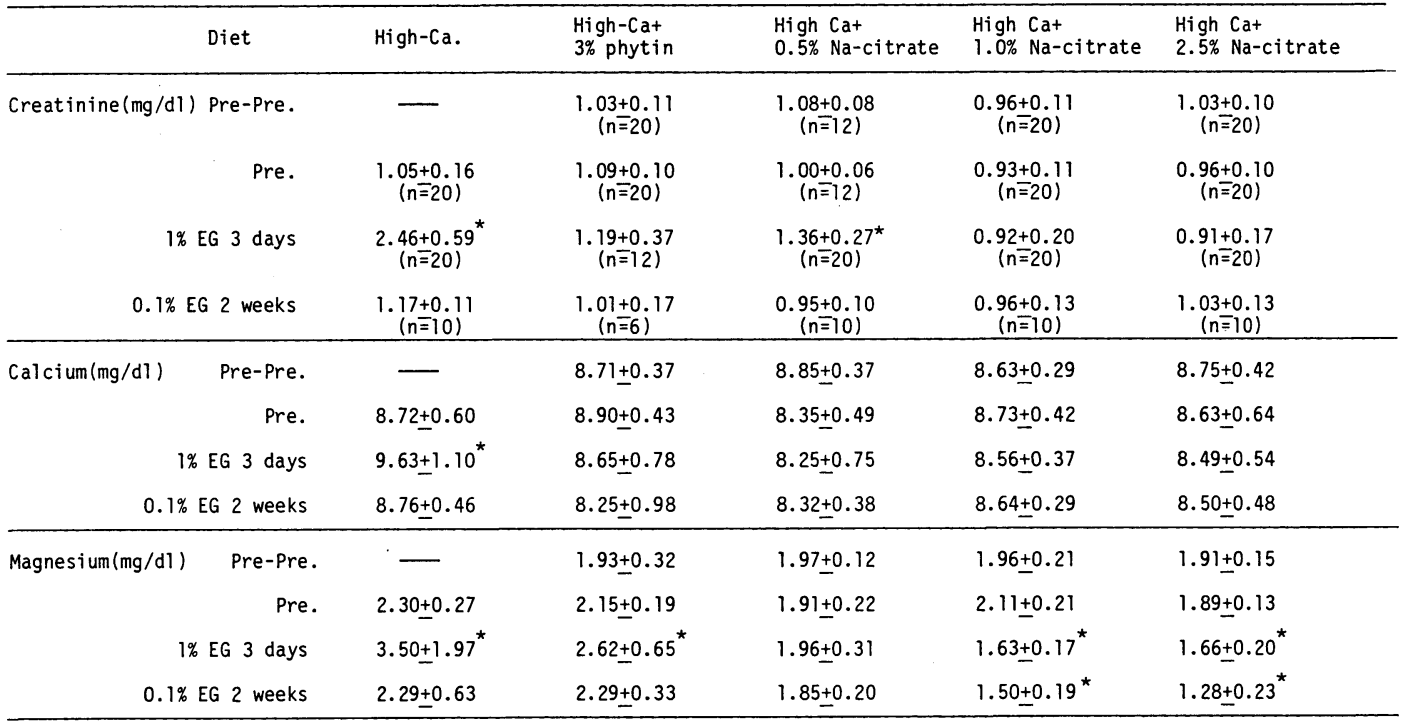

(Pre-Pre.;Rats were fed by high-Ca control diet. The results are expressed as the mean+SD. *;significantly different from Pre-Pre. and Pre-treatment values.) 
Table 3 Dialyexcretions of calcium, magnesium and oxalate (ratio to urinary creatinine)

\begin{tabular}{|c|c|c|c|c|c|}
\hline Diet & High-Ca. & $\begin{array}{l}\text { High Ca+ } \\
3 \% \text { phytin }\end{array}$ & $\begin{array}{l}\text { High-Ca+ } \\
0.5 \% \mathrm{Na}-\mathrm{citrate}\end{array}$ & $\begin{array}{l}\mathrm{High}-\mathrm{Ca}+ \\
1.0 \% \mathrm{Na}-\text { cirate }\end{array}$ & $\begin{array}{l}\mathrm{High}-\mathrm{Ca}+ \\
2.5 \% \mathrm{Na}-\mathrm{citrate}\end{array}$ \\
\hline \multirow[t]{2}{*}{$\mathrm{U}-\mathrm{Ca}(\mathrm{mg} / \mathrm{day}) / \mathrm{U}-\mathrm{Cr}(\mathrm{mg} /$ day $)$} & - & $0.876 \pm 0.443$ & $0.802 \pm 0.473$ & $0.793+0.239$ & $0.813 \pm 0.347$ \\
\hline & $0.778 \pm 0.255$ & $0.451 \pm 0.292 \star$ & $0.910 \pm 0.274$ & $0.880 \pm 0.273$ & $0.485 \pm 0.277^{\star}$ \\
\hline $1 \%$ EG 3 days & $0.687 \pm 0.302$ & $0.406 \pm 0.227 \star$ & $0.693+0.322$ & $0.636 \pm 0.189$ & $0.345+0.149 *$ \\
\hline $0.1 \% E G 2$ weeks & $0.687 \pm 0.302$ & $0.449 \pm 0.130^{\star}$ & $0.734 \pm 0.072$ & $0.660+0.153$ & $0.597 \pm 0.316 *$ \\
\hline $\mathrm{U}-\mathrm{Mg}(\mathrm{mg} /$ day $) / \mathrm{U}-\mathrm{Cr}$ (mg/day) Pre-Pre. & - & $0.689+0.233$ & $0.634 \pm 0.326$ & $0.823+0.209$ & $0.798+0.224$ \\
\hline \multirow{2}{*}{$\begin{array}{l}\text { Pre. } \\
1 \% \text { EG } 3 \text { days }\end{array}$} & $0.814 \pm 0.373$ & $0.674 \pm 0.295$ & $0.586 \pm 0.260$ & $0.610 \pm 0.328$ & $0.654 \pm 0.228$ \\
\hline & $0.756 \pm 0.267$ & $0.784+0.162$ & $0.545 \pm 0.117$ & $0.525 \pm 0.110$ & $0.594 \pm 0.110$ \\
\hline $0.1 \%$ EG 2 weeks & $0.756 \pm 0.250$ & $0.635+0.063$ & $0.646 \pm 0.155$ & $0.499+0.092^{\star}$ & $0.455 \pm 0.186^{\star}$ \\
\hline $\mathrm{U}-0 \mathrm{x}(\mathrm{mg} /$ day $) / \mathrm{U}-\mathrm{Cr}$ (mg/day) Pre-Pre. & - & $0.149 \pm 0.039$ & $0.199 \pm 0.104$ & $0.208 \pm 0.069$ & $0.087 \pm 0.033$ \\
\hline Pre. & $0.198+0.083$ & $0.172 \pm 0.088$ & $0.112+0.025$ & $0.212 \pm 0.084$ & $0.118 \pm 0.076$ \\
\hline 1\% EG 3 days & $0.812 \pm 0.559 * \star$ & $0.954+0.342^{*}$ & $0.760+0.560 *$ & $0.603 \pm 0.317 *$ & $0.701+0.483^{*}$ \\
\hline $0.1 \%$ EG 2 weeks & $0.416 \pm 0.109 * \star$ & $0.295+0.169 *$ & $0.251 \pm 0.175$ & $0.251 \pm 0.183$ & $0.218+0.075^{\star}$ \\
\hline U-Cit (mg/day)/U-Cr(mg/day)Pre-Pre. & - & - & $2.028+0.796$ & - & $2.704+0.845$ \\
\hline $\begin{array}{l}\text { Pre. } \\
\text { Pre }\end{array}$ & - & - & $5.414+0.951 *$ & - & $7.273+2.160^{\star}$ \\
\hline $1 \%$ EG 3 days & - & - & $6: 424 \pm 0.795^{\star}$ & - & $7.378+1.543^{\star}$ \\
\hline $0.1 \%$ EG 2 weeks & - & - & $3.295+1.244$ & - & $3.877+0.569 *$ \\
\hline
\end{tabular}

(Pre-Pre.;Rats were fed by high-Ca control diet. The results are expressed as the mean+SD. *;significantly different from Pre-Pre. treatment values. **; significantly different from Pre-treatment values.)

尿中蓚酸排泄量は $1 \% \mathrm{EG}$ の投与により，すべての 実験群において著明な過蓚酸尿症が認められ，0.1\% EGの投与に拈いても高値が示された。

（3）腎尿細管内蓚酸カルシウム結晶沈着

各食餌群に打ける腎尿細管内の蓚酸カルシウム結晶 沈着を第 1 報に記載した grade に分けて，1\%EG 導 入群及び $0.1 \% \mathrm{EG}$ 維持群の両群に拈いて検討しその 結果はFig. 2に示した。

高カルシウム・フィチン食では対照群である高カル シウム食群に比較すると, 明らかに結晶沈着は抑制さ れて拈り，1\%EG 導入群では grade 0 と判定されたも のが 2 腎にみられ grade 3は認められなかった。更に $0.1 \% \mathrm{EG}$ 維持群では結晶の認められないものが半数 に達し,フィチン投与に伴ら尿中カルシウム排泄量の 减少によるものと考えられると共に，第 1 報で報告し た如く重篤でない過蓚酸尿症といら条件では尿中カル シウム濃度を抑えると結晶形成の抑制のみではなく固 着していない結晶の消失も可能であることが示唆され た.

クエン酸ナトリウム投与群は $0.5 \%$ 群においても明 らかに結晶形成の抑制が認められ，1.0\%及び2.5\%と
投与量が増加するに従って，その抑制効果は増加して おり，2.5\%群では第 1 報で報告した低カルシウム食群 と同じくらいの低い結晶形成率を示した。

（4）腎組織内カルシウム濃度

対照群である高カルシウム食群をも含めた 5 群の腎 組織内カルシゥム濃度は Fig. 3に示した.

高カルシウム・フィチン食では結晶形成の grade 分 類でみられた結果以上に，高カルシウム食群と比較す ると明らかな低值を示し，0.1\%EG 維持群では更に低 値が示された。

クエン酸ナトリウム投与群に扣いても結晶形成の grade 分類でみられた結果と同様に，その投与量に 従って抑制効果が強く発揮されていることが確認され た.

\section{考察}

第 1 報では EG 投与によるラットの腎尿細管内の蓚 酸カルシウム結晶が，摂取カルシウム量あるいは尿中 カルシウム排泄量の増加に従って高度になり，いかに 重篤な過蓚酸尿症が存在していても尿中カルシウム排 泄が少ない状態では結晶形成がなされ難いことを記載 した。本検討では，食飼中のカルシウム含量を最も強 
Fig. 2 Results of renal tubular deposition of caldium oxlate crystal.

a : phytin soudy

〈Phytin study〉

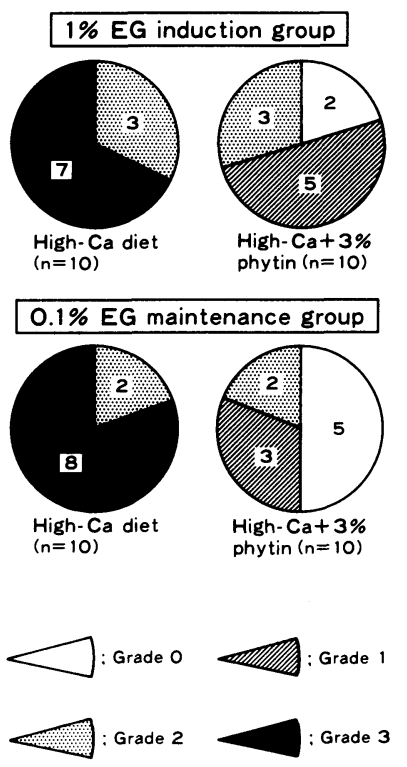

b : citrate study

〈Citrate study〉

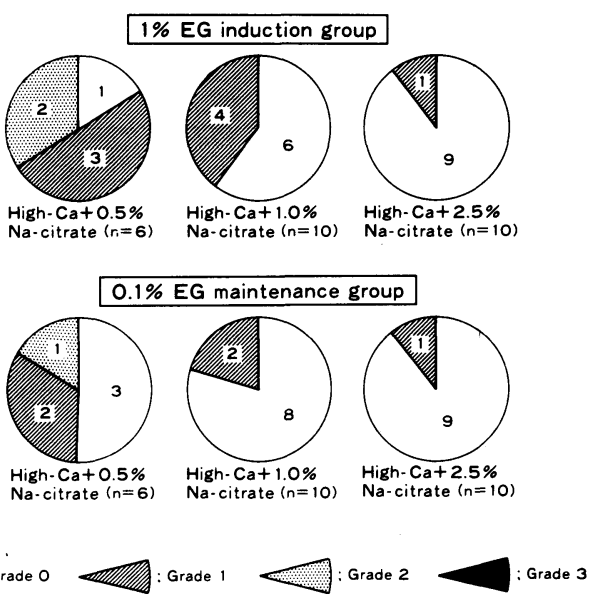

Fig. 3 Calcium cotents of rat kidney.

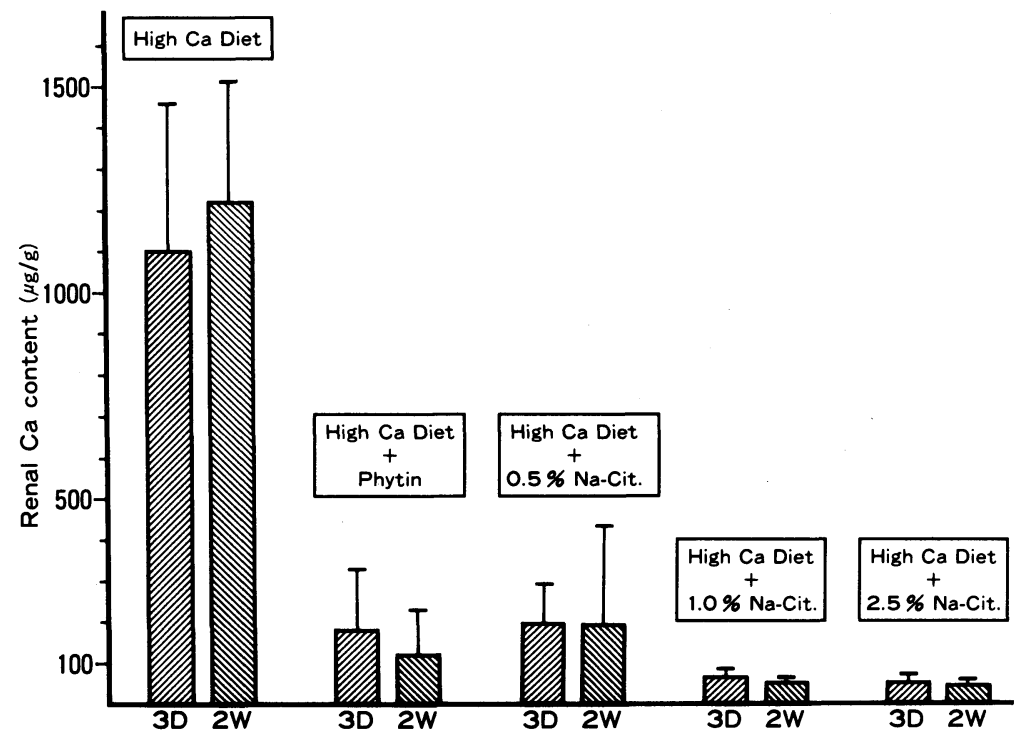

い結晶形成がみられた高カルシウム食とし，これに尿 中カルシウム排泄を抑える目的で米糠から抽出された フィチンを投与し，その結晶形成に与える影響を検討 したものである。その結果，フィチンによる尿中カル シゥム排泄量の減少に伴い, 明らかに結晶形成は抑制
されることが確認された。 この点に関しては，著者ら の米糠療法の臨床的検討でも既に明らかにしている5) ところであり, また, 他の過カルシウム尿症の治療薬 である sodium cellulose phosphate ${ }^{7) や サ イ ア サ ゙ イ ト ゙ ~}$ 系利尿薬8 による長期の治療成績からも示されている 
ように，尿中カルシウム排泄を抑制することによりカ ルシウム結石の発生率が明らかに減少するという事実 を動物実験で裏づける事実であろらと考学られる。

又, 古くから尿路結石症の発生に尿中クェン酸排泄 の低いことが関連すると云われているが910), Robertson ら ${ }^{11}$ 及び Pak ら ${ }^{12)}$ 以前の報告では尿路結石症患 者と正常健康人の間には尿中クェン酸排泄量に差がみ られないとされていた。しかしながら，最近になって カルシウム結石症に怙ける尿中クェン酸排泄量の低下 を示す報告が相次いでみられ(13) 16), 中でも, 低クェン 酸尿症がある種の代謝障害であろうとする Schwille $ら^{17)}$ の報告あるいはこれがクェン酸の尿細管に打ける 再吸収の増加によるものであって, カルシウム結石症 の 1 つの発症因子かも知れないとする Rudman ら ${ }^{18)}$ の報告が注目されているところである。一方, in vitro の実験ではクェン酸そのものの性質が蓚酸カルシウム やリン酸カルシウムの結晶形成を阻害する可能性はよ く知られており, 尿中に扎いてもクェン酸一カルシウム 錯体を形成することによりカルシウムイオン強度が減 少し, 尿中のカルシウム塩の過飽和度が下がることが 示されている19)20).

今回，著者らの $\mathrm{EG}$ 投与による実験結石ではクェン 酸ナトリウムの経口投与により明らかにその形成が抑 制効果が著明になることが示された。実験動物におけ る実験的カルシウム結石に，クエン酸を投与すること によって結石形成の抑制が明らかにされた報告はいま だなされて抢らず, わずかに Gershoff and Andrus ${ }^{21}$ がビタミン $\mathrm{B}_{6}$ 欠乏ラットにマグネシウムを投与する と尿中クエン酸排泄が増加し，マグネシウム投与効果 は単にマグネシウムのみの効果ではなくクェン酸によ る作用も加味されているのではないかとの推察と,

Rajagopal ら ${ }^{22)}$ が EG の毒性を論じる中で EG 投与に よりラット尿中クェン酸が低值を示すことを認め, 腎 内の結晶形成の助長と関連づけている報告が散見され るにすぎない。

今回の著者らの尿化学データからでは, EG 投与に よる尿中クェン酸排泄量の変動については言及できな かったが，クェン酸ナトリウムの投与によって，尿中 クエン酸の排泄が増加することが認められると共に, その過䛢投与ではカルシウムのみならずマグネシウム 代謝に対しても影響をもつ傾向を示す結果がみられ た.

以上の成績は臨床的にも極めて重要なところであ る.クエン酸あるいはクエン酸塩の投与で真に尿中の
クエン酸排泄量が増加するか否かについては, Rudman らはクエン酸制限食と $4.5 \mathrm{~g}$ のクエン酸ナトリウ ム投与とでは尿中クェン酸排泄量に差がみられなかっ たとしている反面, Pak ら ${ }^{23)}$ の最近の報告ではクェン 酸カリウム $60 \mathrm{mEq} / \mathrm{day}$ の投与で $320 \mathrm{mg} / \mathrm{day}$ 以上のク エン酸排泄量が維持できるとされている，著者らもク エン酸の経口投与では吸収されたものがすべて体内で 消費されるものではなく，この結果，尿中排泄量が増 加するものと考えている.

クェン酸投与に伴ら尿中カルシウム排泄量の変化に ついてはいまだ結論のでていないところであるが, Sakhaee ${ }^{24)}$ は尿酸結石症例でのクエン酸ナトリウム及 びクェン酸カリウムの投与効果の比較を扣こなってお り,クェン酸カリウムでは尿中カルシウム排泄量の減 少がみられたとして抢り，腎尿細管内での再吸収増加 にその機序を求めている。このようにクェン酸代謝と 尿路結石症との関連性については不明な点が多いが, 結石症の治療及び発生因子の 1 つとて興味のあると ころであり, 今後の研究の進歩が望まれるところであ る.

\section{まとめ}

ラット実験結石モデルを用いて, 米糠から抽出され たフィチン及びクェン酸ナトリウムを投与し, 苳酸カ ルシゥム結晶形成を抑制する効果を組織学的及び生化 学的に検討し以下の結果を得た。

（1）フィチン投与（3\%/高カルシウム食 $100 \mathrm{~g}$ ) によ り, 尿中カルシゥムは著明に減少し, 且つ腎尿細管内 結晶形成も明らかに抑制された。

(2) クエン酸ナトリウムの投与に扣いては, $0.5 \%$ 投 与群でも明らかに結晶形成の抑制が認められ, $1.0 \%$ 及 び $2.5 \%$ と投与量の増加に従いその抑制効果が増加し た.

本研究の一部は文部省科学研究費 B-59480330の補助に よるものである. 又, 本研究に御協力して頂いた泌尿器科研 究室, 寺本智子嬢に感謝致します. 尚, 本論文の要旨は第72 回日本泌尿器科学会総会 (徳島) シンポジゥムに批いて発表 した.

\section{文献}

1) Ohkawa, T., Ebisuno, S., Kitagawa, M., Morimoto, S. and Miyazaki, Y.: Rice-bran treatment for hypercalciuric patients with calculous disease. J. Urol., 129, 1009-1011, 1983.

2）戎野庄一：特発性過カルシウム尿症を伴ら尿路結 石症に対する rice-bran 療法の研究. I. 臨床的検 討. 日泌尿会誌, 75, 1-9, 1984. 
3）戎野庄一：特発性過カルシウム尿症を伴ら尿路結 石症に対する rice-bran 療法の研究. II. カルシウ ム結合併用についての基礎的検討. 日泌尿会誌, $75,10-15,1984$.

4）戎野庄一：特発性過カルシウム尿症を伴ら尿路結 石症に対する rice-bran 療法の研究. III. ラットに おける rice-bran 投与効果の検討. 日泌尿会誌, $75,16-24,1984$.

5) Ohkawa, T., Ebisuno, S., Kitagawa, M., Morimoto, S., Miyazaki, Y. and Yasukawa, S.: Rice-bran treatment for patients of hypercalciuric stones. J. Urol., in press.

6）戎野庄一, 森本鎮義, 深谷俊郎, 宮崎善久, 安川 修, 澤田佳久, 大川順正：実験的苳酸カルシウム結 石の研究. 日泌尿会誌，76，831-842，1985.

7) Pak, C.Y.C., Peters, P., Hurt, G., Kadesky, M., Fine, M., Reisman, D., Splann, F., Caramela, C., Freeman, A., Britton, F., Sakhaee, K. and Breslau, N.: Is selective therapy of recurrent nephrolithiasis possible? Am. J. Med., 71, 615 $-622,1981$.

8) Yendt, E.R. and Cohanim, M.: Prevention of calcium stones with thiazides. Kidney Int., 13 , 397-409, 1978 .

9) Kissin, B. and Locks, M.W.: Urinary citrates in calcium urolithiasis. Proc. Soc. Exp. Biol. Med., 46, 216-218, 1941.

10) Shorr, E., Almy, T.P., Sloan, M.H., Taussky, H. $\mathrm{H}$. and Toscani, V.: The relation between the urinary excretion of citric acid and calcium : Its implications for urinary calcium stone formation. Science, 96, 587-589, 1942.

11) Robertson, W.G., Peacock, M. and Nordin, B.E. C.: Activity products in stone forming and non-stone forming urine. Clin. Sci., 34, 579 $-594,1968$.

12) Pak, C.Y.C., Holz, K., Zerwekh, J. and Barilla, D.E. : Effects of orthophosphate therapy on tn the crystallisation of calcium salts in urine. mineral Electrolyte Metab., 2, 147-154, 1978.

13) Welshman, S.G. and McGeown, M.G.: Urinary citrate excretion in stone formers and controls. Brit. J. Urol., 48, 7-11, 1976.

14) Pylpchuk, G., Ehrig, U. and Wilson, D.R. : Idiopathic calcium nephrolithiasis. 1. Differences in urine crystalloids, urine saturation with brushite and urine inhibitors of calcification between persons with and persons without recurrent kidney stone formation. Can. Med. Ass. J., 120, 658-665, 1979.

15) Menon, M. and Mahle, C.J.: Urinary citrate excretion in patients with renal calculi. J. Urol., 129, 1158-1160, 1982.

16) Nicar, M.J., Skurla, C., Sakhaee, K. and Pak, C. Y.C.: Low urinary citrate excretion in nephrolithiasis. Urology, 11, 8-14, 1983.

17) Schwille, P.O., Scholz, D., Schwille, K., Leutschaft, R., Goldberg, I. and Sigel, A. : Citrate in urine and serum and associated variable in subgoups of urolithiasis. Nephron, 31, 194-202, 1982.

18) Rudman, D., Kutner, M.H., Redd, S.C. II, Water, W.C. IV, Gerron, G.G. and Bleier, J.: Hypocitraturia in calcium nephrolithiasis. J. Clin. Endocri. Metab., 55, 1052-1057, 1982.

19) Meyer, J.L. and Smith, L.H.: Growth of calciuim oxalate crystals. II. Inhibition by natural urinary crystal growth inhibitors. Invest. Urol., 13, 36-39, 1975.

20) Hallson, P.C., Rose, G.A. and Sulaiman, S.: Raising urinary citrate lowers calcium oxalate and calcium phosphate crystal formation in whole urine. Urol. Int., 38, 179-181, 1983.

21) Gershoff, S.N. and Andrus, S.B.: Dietary magnesium, calcium and vitamin $B_{6}$ and experimental nephropathies in rats: Calcium oxalate calculi, apatite nephrocalcinosis. J. Nutr., 73, 308-316, 1961.

22) Rajagopal, G., Venkatesan, K., Ranganathan, P. and Ramakrishnan, S.: Calcium and phosphorus metabolism in ethylene glycol toxicity in rats. Toxicol. Appl. Pharmacol., 39, 543 $-547,1977$.

23) Pak, C.Y.C., Skurla, C., Brikley, L. and Sakhaee, K.: Augementation of renal citrate excretion by oral potassium citrate administration: Time course, dose frequency schedule, and dose-response relationship. J. Clin. Pharmacol., 24, 19-26, 1984.

24) Sakhaee, K., Nicar, M., Hill, K. and Pak, C.Y. C.: Contrasting effects of potassiuim citrate and sodium citrate therapies on urinary chemistries and crystallization of stone-forming salts. Kidney Int., 24, 348-352, 1983.

（1984年11月 2 日受付） 